\title{
STRATEGI DAKWAH NAHDLATUL ULAMA DAN MUHAMMADIYAH DI KABUPATEN JEPARA DALAM PERSPEKTIF PEMANFAATAN MEDIA MASSA
}

\author{
Achmad Slamet, Aida Farichatul Laila \\ Fakultas Dakwah dan Komunikasi Unisnu Jepara \\ Jl. Taman Siswa (Pekeng) Tahunan Jepara \\ achmadslamet9@gmail.com
}

\begin{abstract}
The Nahdlatul Ulama and Muhammadiyah organizations are the two major organizations in Jepara. The success of this Islamic organization in da' wah can not be separated from the use of good da' wah strategy. A good strategy is supported by good means/media. From the number of da' wah media that can be used as syiar Islam, mass media is considered the most effective and efficient in the current era of technology. This research analyzes the strategy of mass media utilization in Islamic da'wah by two organizations; Nahdlatul Ulama and Muhammadiyah in Jepara District. This research uses the techniques of collecting up to data analysis that refers to qualitative research methodology, to find the data that answer the formulation of the problem that has been decided, about the comparison strategy of mass media utilization in daakwah between the two research objects. So the results of this study will culminate in the use of a number of comparative instruments to determine the similarities and differences, as well as the shortcomings and advantages of the two comparable research objects. After doing research with the data obtained can be concluded that the utilization of mass media used Islamic organization Nahdlatul Ulama in the most effective da'wah is through online media, while the Muhammadiyah organization the most effective use of mass media through print media such as magazine / bulletin. Whereas Equations and Differences. The equality of these two organizations in utilizing the mass media lies in the system of utilization; its own mass media management system and system of cooperation with other mass media. While the difference lies in the mass media products produced by these two Islamic organizations.
\end{abstract}

Keywords: Mass Media, Nahdlatul Ulama, Muhammadiyah. 


\begin{abstract}
Abstrak
Organisasi Nahdlatul Ulama dan Muhammadiyah merupakan dua organisasi besar yang ada di Jepara. Keberhasilan organisasi Islam ini dalam berdakwah tidak lepas dari pemanfaatan strategi dakwah yang baik. Strategi yang baik didukung oleh sarana/media yang baik. Dari banyaknya media dakwah yang bisa digunakan sebagai syiar Islam, media massa dinilai paling efektif dan efisien di era teknologi saat ini. Penelitian ini menganalisis tentang strategi pemanfaatan media massa dalam dakwah Islam oleh dua organisasi ; Nahdlatul Ulama dan Muhammadiyah di Kabupaten Jepara. Penelitian ini menggunakan teknik pengumpulan hingga analisis data yang merujuk pada metodologi penelitian kualitatif, untuk menemukan data-data yang menjawab rumusan masalah yang telah diputuskan, tentang perbandingan strategi pemanfaatan media massa dalam dakwah antardua objek penelitian. Sehingga hasil dari penelitian ini akan berujung pada penggunaan sejumlah instrumen pembanding untuk mengetahui persamaan dan perbedaan, serta kekurangan dan kelebihan dari dua objek penelitian yang diperbandingkan tadi. Setelah melakukan penelitian dengan data yang diperoleh dapat ditarik kesimpulan bahwa pemanfaatan media massa yang digunakan organisasi Islam Nahdlatul Ulama dalam dakwah paling efektif adalah melalui media online, sedangkan pada organisasi Muhammadiyah penggunaan media massa paling efektif lewat media cetak berupa majalah/ bulletin. Sedangkan Persamaan dan perbedaan. Persamaan kedua organisasi ini dalam memanfaatkan media massa terletak pada sistem pemanfaatan ; sistem pengelolaan media massa sendiri dan sistem kerja sama dengan media massa lain. Sedangkan perbedaannya terletak pada produk media massa yang dihasilkan dua organisasi Islam tersebut.
\end{abstract}

Kata Kunci : Media Massa, Nahdlatul Ulama, Muhammadiyah.

\section{A. PENDAHULUAN}

Dakwah adalah komunikasi yang disadari oleh keyakinan (belief) dan tujuan mengajak atau menjalankan ketentuanketentuan Allah dan memperoleh RidhaNya. Bagi muslim sebaik-baiknya aktivitas komunikasi adalah dakwah, yakni aktivitas yang sungguh-sungguh dalam bentuk mengajak manusia mendekat (taqarrub) kepada Allah, dengan memberi dan menjadi teladan kebaikan sebagai suatu kewajiban.

Dakwah harus dilakukan secara sungguh-sungguh dengan mencurahkan pikiran, tenaga, uang dan harta yang dikemas dalam bentuk perencanaan atau perumusan strategi dakwah. Yang demikian mutlak dilakukan karena medan dakwah sangat kompleks baik secara natural maupun sosial, yang sangat menghajatkan akan kajian keilmuan, perencanaan dan strategi (Hamidi, 2010:2).

NahdlatulUlama dan Muhammadiyah merupakan salah satu organisasi Islam terbesar di Indonesia. Nahdlatul Ulama adalah Organisasi yang berdiri pada 31 Januari 1926 dan bergerak di bidang pendidikan, sosial, dan ekonomi. Organisasi ini dinilai sebagai organisasi Kebangkitan Ulama dan Kebangkitan Cendekiawan Islam. Sedangkan Muhammadiyah diambil dari nama Nabi Muhammad SAW, sehingga Muhammadiyah juga dapat dikenal sebagai 
orang-orang yang menjadi pengikut Nabi Muhammad SAW.

Setiap organisasi yang berada pada suatu tempat selalu mengalami perubahan. Perubahan terjadi sebagai respon dari perkembangan yang terjadi di masyarakat. Perubahan dalam masyarakat saat ini sudah menjadi keniscayaan yang patut dimaklumi. Konsekuensi logis dari kenyataan ini ialah bahwa suatu segi kehidupan organisasional yang amat penting untuk selalu mendapatkan perhatian pimpinan puncak suatu organisasi adalah menyesuaikan kemampuan organisasi yang dipimpinnya dalam menghadapi perubahan-perubahan yang pasti selalu terjadi (Siagian, 1994:7). Untuk organisasi perlu memakai pembinaan dan menentukan strategi dalam menjalankan aktivitas agar organisasi tersebut mampu menyesuaikan diri.

Pentingnya strategi dakwah adalah untuk mencapai tujuan, sedangkan pentingnya suatu tujuan adalah untuk mendapatkan hasil yang diinginkan (Cholis, 2006:54). Fokus perhatian dari ahli dakwah memang penting untuk ditujukan kepada strategi dakwah, karena berhasil tidaknya kegiatan dakwah secara efektif banyak ditentukan oleh strategi dakwah itu sendiri.

Strategi berasal dari kata Yunani strategos yang berarti jenderal. Oleh karena itu, kata strategi secara harfiah berarti "Seni para Jenderal" (Steiner \& Miner, 1988 :18). Secara khusus strategi lebih menekankan pada penempatan sasaran dan memastikan implementasi secara tepat. Artinya, ketika organisasi memiliki strategi dalam menjalankan aktivitasnya, maka secara tidak langsung organisasi tersebut tengah menempatkan sasaran dan memastikan implementasi kebijakan yang akan dilakukan.

Sedangkan dakwah sebagai suatu kegiatan komunikasi keagamaan dihadapkan kepada perkembangan dan kemajuan teknologi komunikasi yang semakin canggih, memerlukan suatu adapasi terhadap kemajuan itu. Artinya dakwah dituntut untuk dikemas dengan terapan media komunikasi sesuai dengan aneka mad'u (komunikan) yang dihadapi (Ilaihi, 2010:33).

Saat ini, laju perkembangan zaman berpacu dengan tingkat kemajuan ilmu pengetahuan dan teknologi, tidak terkecuali teknologi komunikasi yang merupakan suatu sarana yang menghubungkan suatu masyarakat dengan masyarakat di bumi lain. Kecanggihan teknologi komunikasi ikut mempengaruhi seluruh aspek kehidupan manusia termasuk di dalamnya kegiatan dakwah sebagai salah satu pola penyampaian informasi dan upaya transfer ilmu pengetahuan.

Hal tersebut menunjukkan bahwa proses dakwah bisa terjadi dengan menggunakan berbagai sarana/media, karena perkembangan ilmu pengetahuan dan teknologi sangat memungkinkan hal itu. Ilmu pengetahuan dan teknologi sangat berdampak positif sebab dengan demikian pesan dakwah dapat menyebar sangat cepat dengan jangkauan dan tempat yang sangat luas pula.

Dalam suatu proses dakwah, seorang juru dakwah (da'i) dapat menggunakan berbagai sarana atau media. Salah satu unsur keberhasilan dalam berdakwah adalah 
kepandaian seorang $d a^{\prime} i$ dalam memilih dan menggunakan sarana atau media yang ada (Adi Sasono, Didin Hafiudin, A.M. Saefuddin et. all., 1998: 154).

Untuk mencapai sasaran dakwah tersebut, da'i dapat memilih salah satu atau gabungan dari beberapa media, bergantung pada tujuan yang ingin dicapai, pesan yang disampaiakn dan teknik yang dipergunakan. Mana yang terbaik dari sekian banyak media itu tidak dapat ditegaskan dengan pasti sebab masingmasing memiliki kelebihan dan kekurangan (Effendy, 1986:37).

Dalam arus modernisasi ini, para da'i harus mampu menyesuaian diri dengan mempergunakan serta memanfaatkan media itu. Di negara-negara barat dan di negara-negara maju, banyak dijumpai penggunaan media ini dalam misi relegius yang diselenggarakan oleh perkumpulan keagamaan, baik melalui media cetak maupun elektronik (Djamalul Abidin, 1996: 122).

Peluang dakwah Islam akan semakin terbuka lebar ketika para juru dakwah (da'i) mampu memanfaatkan media massa dengan meminimalisir dampak negatif dan memaksimalkan dampak positif dari media yang ada. Diperlukan sebuah strategi baru oleh para da'i, terutama dalam metode serta pemanfaatan media massa dan teknologi komunikasi dalam aktivitas dakwah tersebut (Mahmudin, 2004:52).

Pemanfaatan media massa tidak lepas dari keberadaan media massa yang memang sangat berpengaruh terhadap kehidupan masyarakat. Media massa mampu membentuk opini bahkan mengubah perilaku masyarakat.
Kegiatan dakwah menjadi semarak dengan merambah dunia media massa yang terintegrasi. Dalam perkembanganya, media mampu melakukan rekonstruksi sosial dalam membentuk opini publik terhadap realitas di tengah-tengah masyarakat.

Keberadaan media massa di tengah masyarakat sangat urgen bahkan mampu mempengaruhi pola pikir dan perilaku masyarakat. Ketika sebuah peristiwa dikonstruksi media menjadi tayangan bermuatan dakwah dan diakses publik yang meliputi umat Islam selaku mad'u, tentu konstruksi media atas teks atau tayangan dalam konstruk dakwah merupakan harapan bagi pengembangan dakwah melalui media massa yang diyaikini pengaruhnya signifikan. Media massa diyakini dapat memberi kesan khusus dan efek terhadap individu, kelompok atau lingkungan tertentu (John, 2009:410).

Dapatlah diketahui bahwa kepentingan dakwah terhadap adanya sarana atau media yang tepat dalam memanfaatkan media terhadap dakwahnya sangat urgen. Sehingga dapat dikatakan dengan pemanfaatan media massa (sarana/ media dakwah) akan lebih mudah diterima oleh komunikan (mad'u-nya) ketika proses berlangsungnya dakwah.

Dari uraian di atas, penulis merasa tertarik untuk membandingkan organisasi Islam Nahdlatul Ulama dan Muhammadiyah di Jepara dalam strategi dakwahnya dengan memfokuskan pada pemanfaatan media massanya.

Karena kedua organisasi Islam tersebut merupakan organisasi terbesar yang ada di Jepara. Dan keberhasilan dua

ISSN : 2085-3521, E-ISSN : 2548-9054 
organisasi dakwah ini untuk tetap eksis dan digandrungi banyak masyarakat, pasti tidak lepas dari perannya dalam memanfaatkan strategi dakwah yang efektif dan kreatif. Apalagi di tengah beragam dimensi kehidupan tradisional maupun modern yang berkembang di Jepara saat ini.

\section{B. METODE PENELITIAN}

Jenis penelitian kualitatif yakni penelitian yang bertujuan untuk menggambarkan secara sistematik dan akurat mengenai fakta dan karakteristik tentang populasi atau bidang tertentu yang menghasilkan suatu uraian yang dikaji dari sudut pandang yang utuh, komprehensif dan holistic. Yang digambarkan dalam penelitian ini adalah strategi dakwah Nahdlatul Ulama dan Muhammadiyah perspektif pemanfaatan media massa di Kabupaten Jepara.

\section{Sumber Data}

Penelitian ini merupakan penelitian kualitatif, maka jenis data yang diperlukan adalah data yang berbentuk kualitatif, yaitu data yang berbentuk kata, kalimat, skema dan gambar (Khoiri, t.t.:71). Sehingga dalam penelitian ini penulis menggunakan jenis data yang berbentuk kata dan kalimat.

Sedangkan yang dimaksud sumber data ialah subjek dari mana data diperoleh (Arikunto, 1992:172). Secara umum sumber data terdiri dari (Umar, 2009:42).

a. Data primer

Data Primer adalah data yang didapat dari sumber pertama baik dari individu atau perseorangan seperti hasil wawancara atau hasil kuesioner yang biasa dilakukan oleh peneliti.
Sumber data primer dalam penelitian ini diperoleh dari keterangan saksi mata, yakni anggota organisasi dakwah Islam. Data primer berupa data dalam bentuk pertanyaan secara umum untuk menghasilkan jawaban, data kata-kata (teks) atau data gambar (picture), serta informasi dari sejumlah kecil individu/situs (Umar, 2009:157). Data kualitatif meliputi observasi, wawancara (interview), dokumentasi pribadi dan resmi, foto, rekaman, gambar, dan percakapan informal.

b. Data sekunder

Data Sekunder yaitu sumber data tertulis yang merupakan sumber data yang tidak bisa diabaikan, karena dari awal sudah mempunyai tujuan memperoleh suatu informasi yang diperlukan (Umar, 2009:158). Dan melalui sumber data tertulis akan diperoleh data yang dapat dipertanggung jawabkan validitasnya. Sedangkan data sekunder disajikan penulis dengan menggunakan buku-buku yang bersangkutan dengan kajian penelitiannya.

\section{Teknik Pengumpulan Data}

Metode ialah tehnik atau cara yang digunakan oleh peneliti untuk mengumpulkan data (Riduwan, 2005:69). Dengan kata lain pengumpulan data merupakan suatu langkah yang sangat penting dalam metode ilmiah atau dalam melakukan sebuah penelitian. Karena data yang dikumpulkan untuk digunakan sebagai sumber data penelitian.

Salah satu tahap yang penting dalam proses penelitian ini adalah tahap pengumpulan data. Dalam penelitian ini metode pengumpulan data yang penulis gunakan adalah: 


\section{a. Metode Wawancara (interview)}

Metode wawancara (inteview) adalah sebuah proses interaksi komunikasi yang dilakukan oleh setidaknya dua orang, atas dasar ketersediaan dan dalam setting alamiah, dimana arah pembicaraan mengacu pada tujuan yang telah ditetapkan dengan mengedepankan trust sebagai landasan utama dalam proses memahami (Khoiri, 2007:48).

Peneliti dalam hal ini berkedudukan sebagaiinteviewer, mengajukan pertanyaan, meneliti jawaban, meminta penjelasan, mencatat dan menggali pertanyaan lebih dalam. Di pihak lain, sumber informasi (inteview) menjawab pertanyaan, memberi penjelasan dan kadang-kadang juga membalas pertanyaan. Wawancara merupakan metode pengumpulan data yang digunakan untuk memperoleh informasi langsung dari sumbernya.

Pengumpulan data dengan mengajukan pertanyaan secara langsung oleh pewawancara (pengumpul data) kepada responden dan jawaban-jawaban responden dicatat lalu direkam dengan alat perekam (tape recorder). Metode wawancara yaitu suatu pengumpulan data dengan tanya jawab sepihak yang dikerjakan secara sistematis dan berlandaskan kepada tujuan penelitian (Hadi, 1991: 192).

Beberapa hal yang perlu diperhatikan seorang peneliti saat mewawancarai responden adalah intonasi suara, kecepatan berbicara, sensitifitas pertanyaan, kontak mata, dan kepekaan nonverbal. Dalam mencari informasi, peneliti melakukan dua jenis wawancara, yaitu autoanamnesa (wawancara yang dilakukan dengan subjek atau responden) dan aloanamnesa (wawancara dengan keluarga responden) (Sugiyono, 2008: 227).

Beberapa tips saat melakukan wawancara adalah mulai dengan pertanyaan mudah, mulai dengan informasi fakta, hindari pertanyaan multiple, jangan menanyakan pertanyaan pribadi sebelum building raport, ulang kembali jawaban untuk klarifikasi, berikan kesan positif, dan kontrol emosi negatif.

Dalam penelitian ini yang menjadi responden adalah salah satu pengurus dari kedua organisasi, yaitu ; Ketua Organisasi Dakwah Nahdlatul Ulama dan Muhammadiyah Cabang Jepara, Bagian Hubungan Masyarakat (Humas) Organisasi Dakwah Nahdlatul Ulama dan Muhammadiyah Cabang Jepara, Bagian Informasi Organisasi Dakwah Nahdlatul Ulama dan Muhammadiyah Cabang Jepara serta bagian dakwah dalam Organisasi Dakwah Nahdlatul Ulama dan Muhammadiyah Cabang Jepara. Yang memang merupakan pihak yang kompeten menjawab pertanyaan yang penulis ajukan. Metode Dokumentasi

b. Metode dokumentasi

Dokumentasi adalah sebuah metode yang mengumpulkan dokumendokumen yang berupa data tertulis yang mengandung keterangan dan penjelasan serta pemikiran tentang fenomena yang masih aktual. Metode dokumentasi berawal dari menghimpun dokumen, memilihmilih dokumen sesuai dengan tujuan penelitian, menerangkan dan mencatat serta menafsirkannya serta menghubunghubungkan dengan fenomena lain (Syam, 1991:109). 
Metode dokumentasi merupakan mencari data mengenai hal-hal atau variable yang berupa catatan, transkip, buku, surat kabar, majalah, prasasti, notulen rapat, legger, agenda dan sebagainya. Untuk memperoleh data dari beberapa dokumen sebagai pelengkap. Yang dapat memperjelas metode yang lain seperti inteview dan observasi, seperti :

1) Profil Organisasi Nahdlatul Ulama dan Muhammadiyah Kabupaten Jepara

2) Jadwal Kegiatan Organisasi Nahdlatul Ulama dan Muhammadiyah Kabupaten Jepara

3) Dokumentasi kegiatan dakwah dalam strategi pemanfataan media massa nya.

c. Metode Observasi/pengamatan

Observasiadalah proses pengumpulan data dengan cara mengamati kegiatan. Hasil pengamatan kemudian dibuat catatan sebagai data dalam penelitian. Obyek observasi dalam penelitian ini meliputi:

Strategi dalam kegiatan dakwah Islam yang menggunakan media massa. Kemudian Sistem kerja sebuah organisasi dakwah dalam menggunakan media massa.

\section{Teknik Analisis Data}

Menurut Daymon dan Holloway (2008, 369) Analisis data kualitatif secara umum dapat dilakukan sebagai berikut (Daymon \& Haoloway, 2008:241):

\section{a. Proses Reduksi}

Prosesreduksiadalah proses mengolah data dari data yang tidak atau belum tertata menjadi data yang tertata. Dalam proses reduksi ini terkandung aspek pengeditan, pemberian kode dan pengelompokan data sesuai dengan kategorisasi data. Proses reduksi bertujuan untuk mengolah data yang diperoleh melalui pengumpulan data agar menjadi data yang dapat dipahami dan tersusun secara sistematis.

b. Penyajian Data

Alur kegiatan analisis data yang kedua adalah penyajian data yaitu menggelar data dalam sekumpulan informasi (Daymon \& Haoloway, 2008:242). Dengan cara ini diharapkan mempermudah penarikan kesimpulan, pengambilan verifikasi atau bisa melengkapi data yang masih kurang melalui pengumpulan data tambahan dan reduksi data.

c. Verifikasi

Kesimpulan yang diambil dari data yang terkumpul perlu diverifikasi terusmenerus selama penelitian berlangsung agar data yang didapat dijamin keabsahannya dan obyektivitasnya (Daymon \& Haoloway, 2008:243). Analisa data kualitatif ini merupakan upaya terusmenerus dan terjalin hubungan yang saling terkait antara kegiatan reduksi data, serta penarikan kesimpulan. Jika kesimpulan yang diambil masih kurang maka dilakukan pengumpulan data tambahan yang dianalisis melalui kegiatan yang sama.

Ilustrasi dari prosedur di atas adalah data dikumpulkan saat peneliti di lapangan, peneliti pengajukan pertanyaan baik itu terstuktur maupun tidak terstruktur kepada informan. Jawaban dari informan tersebut dipilih dan disederhanakan dalam catatan.

Data-data tersebut kemudian disajikan untuk kesimpulan sementara. Langkah berikutnya adalah kesimpulan tersebut diverifikasi untuk disempurnakan sehingga 
memperoleh kejelasan pemahaman tentang apa yang hendak di ungkap dalam penelitian (Maryono, 2003:51-52). dan secara harfiah penelitian ini adalah bermaksud untuk mendeskripasikan mengenai situasi-situasi atau kejadian-kejadian yang terkait dengan strategi dakwah di kedua organisasi Islam ; Nahdlatul Ulama dan Muhammadiyah (Suryabrata, 1983:16-17).

Adapun metode analisis data yang penulis gunakan adalah deskriptif kualitatif, yaitu proses analisis yang didasarkan pada kaidah deskriptif dan kualitatif. Kaidah deskriptif merupakan proses analisis terhadap seluruh data yang telah didapatkan dan diolah, kemudian hasil analisa tersebut disajikan secara keseluruhan. Sedangkan kaidah kualitatif adalah proses analisis yang ditujukan untuk mengembangkan teori bandingan dengan tujuan untuk menemukan teori baru, berupa penguatan terhadap teori lama, maupun melemahkan teori yang telahmada tanpa menggunakan rumus statistik (Danim, 2002: 41). Analisa deskriptif kualitatif yang digunakan dalam penelitian ini bersifat perbandingan (komparasi), yaitu data-data lapangan yang diperoleh dianalisa dengan membuat perbandingan antar data organisasi dan juga perbandingan antara data lapangan dengan konsep ukhuwah Islamiyah.

\section{HASIL DAN PEMBAHASAN}

\section{Pemanfaatan Media Massa pada Organisasi Nahdlatul Ulama}

Peran media massa dalam sebuah organisasi sangat dekat hubungannya dengan peran public relations. Aktivitas Public Relations (PR) selalu dihubungkan dengan aktivitas komunikasi dalam organisasi
PR, sesuai dengan peran dan fungsinya, bertindak sebagai komunikator yang mewakili organisasi untuk menyampaikan atau menyebarluaskan pelbagai informasi kepada publik yang dijadikan sasaran, baik publik internal maupun publik ekstrenal (Ruliana, 2014:177). Oleh karena itu, dalam Ilmu Komunikasi PR merupakan suatu metode komunikasi dan telah menjadi begian dari objek studi ilmu komunikasi.

Media massa pada dasarnya dapat dibagi menjadi dua kategori, yakni media massa cetak dan media elektronik. Media cetak yang dapat memenuhi kriteria sebagai media massa adalah surat kabar dan majalah. Sedangkan media elektronik yang memenuhi kriteria media massa adalah radio, televisi, film, media on-line (internet).

Organisasi Nahdlatul Ulama Kabupaten Jepara mempunyai lembaga yang menangani tentang publikasi media dan pusat informasi yaitu Lembaga Ta'lif wa Nasyr (LTNNU). Lembaga dakwah media pada Nahdlatul Ulama ini menjadi bagian dari Public Relation dalam sebuah organisasi. Karena keduanya sama-sama bertindak sebagai komunikator organisasi yang akan menyampaikan pesan atau informasi yang berkaitan dengan kebijakankebijakan organisasi kepada khalayak (Ruliana, 2014:196).

Pada Muktamar ke-33 Nahdlatul Ulama telah memutuskan beberapa perubahan AD/ART NU, salah satunya adalah posisi lajnah yang pada AD/ART lama berfungsi hanya untuk menangani bidang-bidang khusus, pada AD/ART selanjutnya berubah menjadi lembaga. 
Pasal 16 ART NU telah mengatur bahwa perangkat organisasi Nahdlatul Ulama terdiri dari : (1) Lembaga (2) Badan Otonom; dan (3) Badan Khusus.

Terkait dengan lembaga, telah dinyatakan dalam pasal 17 ART NU bahwa "lembaga adalah perangkat departementasi organisasi Nahdlatul Ulama yang berfungsi sebagai pelaksana kebijakan Nahdlatul Ulama berkaitan dengan kelompok masyarakat tertentu dan/ atau yang memerlukan penanganan khusus. Salah satu lembaga yang ada dalam perangkat lembaga NU tersebut adalah Lembaga Ta'lif wan Nasyr (LTNNU) yang bertugas mengembangkan penulisan, penerjemahan dan penerbitan kitab/buku serta media informasi menurut alhusunnah wal Jamaa'ah.

LTNNU memiliki peran yang sangat penting dalam mencerdaskan warga NU sekaligus menunjukkan eksistensi NU sebagai sebuah organisasi. Melalui gerakan pengembangan penulisan, sehingga budaya literasi akan semakin kental. Pada akhirnya, ketika warga NU memiliki kemampuan yang unggul di bidang penulisan, akan menjadi kekuatan baru bagi NU dalam transformasi nilai-nilai aswaja, melalui jalur literasi di lintas media. Warga NU akan semakin mudah untuk masuk dalam dunia pers dan jurnalistik, sehingga akan semakin memperkokoh eksitensi NU sebagai jam'iyyah, sesuai dengan adagium klasik, "Barang siapa menguasai media, dia akan menguasai dunia".

Kematangan kompetensi di bidang penulisan juga memiliki semangat luhur, karena berkohesi dengan pelestarian budaya menulis yang telah lama dilakukan oleh ulama salaf untuk mentransformasikan keilmuan sekaligus menjaga agar ilmu dan pemikiran tetap lestari melalui literasi. Kini, budaya itu telah terdegradasi. Budaya literasi telah bergeser menjadi budaya orasi, dakwah tulisan telah tetindih dengan dakwah lisan. Kitab sudah jarang ditulis karena dianggap tidak ekonomis. Budaya informasi yang instan membuat google menjadi panutan. Postingan yang terhampar dunia maya dianggap lebih dari cukup menjawab semua persoalan masyarakat, karena memang nyaris tidak ada satupun persoalan yang tidak ada solusinya di intenet.

Dalam bidang penerjemahan, LTNNU memiliki peran untuk "membumikan" karya-karya para ulama yang ditulis dengan menggunakan bahasa asing. Upaya penerjemahan niscaya dilakukan agar masyarakat dapat lebih mudah memahami isi karya ulama tesebut. Di bidang penerbitan kitab/buku, LTNNU akan menjadi "penyelamat" pemikiran dan ilmu para ulama melalui gerakan kodifikasi. Hal ini karena banyak kyai NU yang ingin mencurahkan gagasannya dalam sebuah kitab/buku, namun seringkali teganjal teknis penulisan dan penerbitan. Kitab/ buku yang akan ditebitkan oleh LTNNU tersebut, akan menjadi wadah bagi perasan keringat intelektual para ulama dan menjaganya agar tetap lestari dapat diwariskan kepada para generasi penerus.

LTNNU sebagai penyedia media dan informasi, akan menjadi "corong" bagi setiap aktifitas NU, baik secara struktural maupun kultural. LTNNU juga akan menjadi penjaga data dan informasi sekaligus rujukan bagi segenap warga $\mathrm{NU}$ 
dan seluruh masyarakat pada umumnya yang ingin memperoleh informasi tentang NU.

Dari banyaknya media massa yang bisa dimanfaatkan sebagai sarana dakwah, melalui media TV, radio, majalah, koran ataupun website, untuk saat ini LTNNU lebih memilih fokus merawat dan mengembangkan website resmi milik PCNU. Namun LTNNU juga banyak bekerja sama dengan media lain sebagai jalan alternatif untuk tetang berdakwah lewat media massa.

\section{a. Pemanfaatan Media Cetak}

Tidak dapat dipungkiri bahwa media cetak adalah media komunikasi massa yang mempunyai pengaruh cukup besar bagi penyebaran pesan-pesan atau informasi. Dalam hal ini media massa sebagai media penyebaran informasi bisa digunakan sebagai media untuk menyampaikan dakwah islamiyah. Pada masa kini publikasi tercetak (printed publications) sangat efektif untuk penyampaian informasi kepada khalayak ramai.

Berdakwah menggunakan sarana media cetak sudah banyak dilakukan pada organisasi-organisasi keislaman saat ini. LTNNU sebagai wadah informasi bagi organisasi Nahdlatul Ulama juga memanfaatkan media cetak sebagai media dakwah. Dari klasifikasi media cetak berupa; surat kabar, tabloid, majalah ataupun bulletin. LTNNU memilih ingin menerbitkan bulletin sebagai produk dakwah media pada organisasi NU ini.

Bagi LTNNU masyarakat perlu diberi taushiyah keagamaan dan informasi secara rutin agar keimanan dan pengetahuannya semakin meningkat. Salah satu upaya yang akan dilakukan untuk mewujudkan hal tersebut adalah dengan menerbitkan buletin secara rutin tiap hari Jumat. Bulletin yang direncanakan akan diterbitkan oleh LTNNU Jepara ini bernama "Bulletin Ta'lif" yang nantinya terbit setiap hari jumat dan didistribusikan ke masjid-masjid yang ada di Kabupaten Jepara. Sasaran dari bulletin tersebut adalah warga nahdliyyin dan masyarakat umum.

Namun sejauh ini pemanfaatan media massa cetak pada organisasi Nahdlatul Ulama Jepara belum terlaksana secara baik. Beberapa hal yang menyebabkan belum terealisasikan "bulletin ta'lif" ini karena faktor pendanaan, konsistensi penganggaran, dan sumber daya manusia. Namun ada keinginan untuk merealisakan bulletin ta'lif terwujud dengan bekerjasama dengan UNISNU (Unisversitas Nahdlatul Ulama) Jepara.

\section{b. Pemanfaatan Media Elektronik}

Media elektronik merupakan media yang efektif dalam menyampaikan pesan dalam hal ini pesan keagamaan kepada khalayak penerima dakwah, pada era sekarang ini media elektronik dalam hal ini TV maupun radio sangat efektif untuk menyampaikan pesanpesan kepada khalayak ramai. Beberapa organisasi keislaman sudah banyak yang memanfaatkan media TV dan Radio sebagai sarana dakwah. Namun organisasi Nahdlatul Ulama belum memanfaatkan media TV dan Radio sebagai sarana dakwahnya. 
Organisasi Nahdlatul Ulama dalam hal pemanfaatan media massa elektronik masih menggunakan sistem kerjasama dengan media lain. Organisasi NU Jepara memilih bekerjasama dengan media elektronik Radio daripada Televisi. Stasiun radio yang bekerjasama dengan organisasi NU Jepara ini adalah Radio R-lisa FM Jepara.

Radio R-lisa mempunyai visi menjadikan radio R-lisa FM sebagai satusatunyaradiopenyiaran profesionaldiJepara yang unggul dengan tetap berpegang teguh pada nilai-nilai religiusitas. Radio R-lisa bertujuan untuk mewujudkan manusia unggul yang siap menghadapi globalisasi dan tetap mengedepankan relogiusitas sesuai dengan budaya mesyarakat Jepara yang berluktur agamis.

Program acara penyiaran dakwah islam pada radio R-lisa bernama "Tombo Ati" ini merupakan program khusus dari Organisasi Nahdlatul Ulama sebagai bentuk dakwah melalui media massa. Program Tombo Ati adalah sebuah acara reguler yang berorientasi untuk menambah pengetahuan tentang agama islam yang dikemas dengan acara yang berbentuk siaran hasil rekaman pengajian "tasawuf al hikam" yang disampaikan oleh KH. Imron Djamil.

Program acara reguler atau harian Tombo Ati (Kajian Al- Hikam Pagi) ini setiap hari disiarkan sebagai acara khusus dakwah islam. Acara tersebut dikemas berupa siaran ulang hasil rekaman pengajian bersama $\mathrm{KH}$. Imron Djamil yang diputar dalam sehari 3 kali yang masingmasing berdurasi 30 menit, yaitu pukul
05.-00 sampai 05.30, kemudian pukul 12.0012.30 dan pukul 17.00-17.30.

Selain program reguler Tombo Ati, Organisasi Nahdlatul Ulama juga mempunyai program siaran khusus yang disiarkan saat bulan Ramadhan. Program acara tersebut bernama "Kajian Islam", yaitu dialog agama yang membahas tentang ibadah puasa atau hal yang berkaitan tentang bulan Ramadhan. Narasumber yang mengisi acara tersebut dari Banom dan PCNU Jepara. Walaupun sifatnya sementara karena hanya ada di bulan Ramadhan, tetapi termasuk strategi NU Jepara dalam menyiarkan dakwah islamiyah lewat media massa elektronik.

c. Pemanfaatan Media Online

Media Massa Online atau Internet merupakan media dan sumber informasi yang paling canggih saat ini, sebab teknologi ini menawarkan berbagai kemudahan, kecepatan, ketepatan akses dan kemampuan menyediakan berbagai kebutuhan informasi setiap orang kapan saja, dimana saja dan pada tingkat apa saja.

Hadirnya akses internet merupakan media yang tidak bisa dihindari karena sudah menjadi peradaban baru dalam dunia informasi dan komunikasi tingkat global. Dengan adanya akses internet, maka sangat banyak informasi yang dapat dan layak diakses oleh masyarakat intenasional, baik untuk kepentingan pribadi, pendidikan, bisnis, dan lain-lain. Di mana munculnya jaringan internet dianggap sebagai sebuah revolusi dalam dunia komunikasi informasi.

Dari banyaknya ragam media online, Website dinilai paling efektif dalam 
menyebarkan informasi juga sebagai media dakwah organisasi Nahdlatul Ulama Jepara. Jika dibandingkan dengan mengelola media massa cetak, pengelolaan media massa online berupa website menjadi pilihan dalam kegiatan berdakwah. Selain karena efektif dan murah, manajemen pengelolaannya juga mudah.

Website resmi milik PC NU Jepara ini dikelola oleh LTNNU, dengan alamat url nujepara.or.id. Ini merupakan bentuk pemanfaatan teknologi internet oleh organisasi untuk menyediakan informasi dan berkomunikasi secara efektif dan efisien. Website nujepara.or.id merupakan sebuah media interakif yang dapat menjangkau pembacanya dalam waktu yang singkat dan cepat.

Website nujepara.or.id diluncurkan pada 24 April 2016 pada saat acara puncak kegiatan Harlah NU ke 93 di depan gedung NU Jepara. Dengan diluncurkan website ini, diharapkan dapat menjadi rujukan utama warga nahdliyin dalam menerima informasi yang aktual dan terpecaya. Selain itu, apa yanga da dalam website resmi NU tersebut diharapkan mampu menangkal faham-faham garis yang mengusik keutuhan NKRI.

Selainmempublikasikankepengurusan NU dan lembaga-lembaganya, nujepara. or.id juga menyajikan berbagai informasi dan bacaan untuk warga nahdliyin. Di dalamnya banyak orang dapat membaca berita tentang kegiatan-kegiatan terbaru NU Jepara, materi khutbah, opini, figur, hasil bathsul masail dan berbagai informasi lainnya. Tentunya, sajian informasi ini disajikan oleh NU Jepara untuk warganya sebagai rujukan dalam beragam dan bermasyarakat.

Sampai awal Nopember 2016, ada 27.964 orang yang telah menunjungi website nujepara.or.id dengan 61,668 halaman di baca, walaupun belum begitu banyak pembaca, setidaknya ini menjadi awal yang baik untuk menjadikan nujepara. or.id sebagai pusat informasi untuk warga NU Jepara.

Hingga awal nopember 2016, crew admin sudah memposting 190 berita. 5 bahtsul masail, 4 esai, 2 interaktif ramadhan, 7 figur, 6 opini, 10 khutbah, 18 berita bola, 2 resensi buku, dan 2 kolom. Total seluruh postingan di website sebanyak 246 post.

Karena bagi LTNNU, $\mathrm{Nu}$ saat ini sangat membutuhkan sekali peran media. Setidaknya dengan adanya website resmi NU Jepara ini, semua kegiatan yang dilakukan banom bisa terpublikasikan. Ide dan gagasan yang dicetuskan semua lembaga NU bisa ditulis dan diposting, sehingga bisa diakses dan dibaca banyak orang, khusunya warga NU.

Pada periode ini, LTNNU fokus mengelola website sebagai sarana media dakwah. Periode sebelum ini memang tidak ada website resmi yang memuat berita kegiatan, sehingga seluruh dokumentasi kegiatan acara hanya berupa foto dalam album tanpa caption.

\section{Gambar 1}

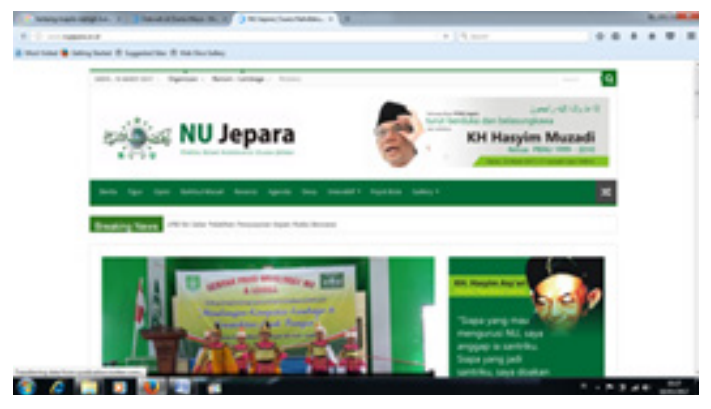


Gambar 2

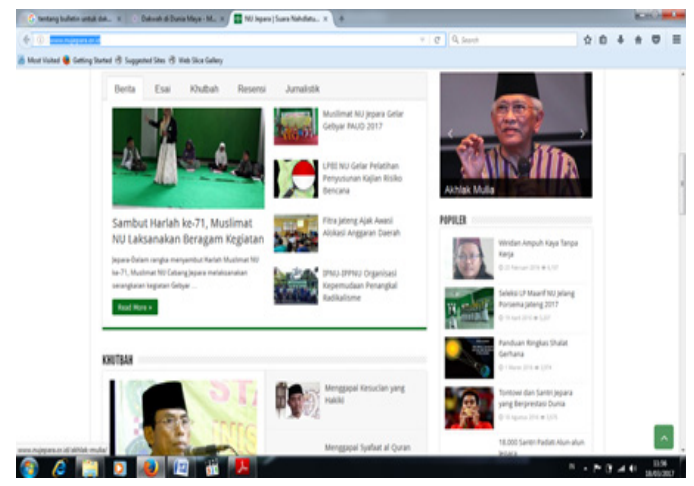

Sumber : http://www.nujepara.or.id/

Konten yang terdapat dalam website NU Jepara diantara ada : Berita, esai, khutbah, bahtsul masail, opini, figur, resensi dan jurnalistik. Adanya konten khutbah berangkat dari kerprihatinan LTNNU tentang marakknya islam radikal yang isi khotbahnya banyak fundamentalis. Meskipun di Jepara tidak begitu kentara, namun benih-benihnya tetap ada..

Keinginan NU adalah menyajikan tulisan khutbah yang teduh yang berasal dari kiai-kiai Jepara. Beberapa kiai yang intens menulis dalam kolom khutbah diantaranya adalah ; KH Nafiuddin Hamdan - Wakil Rois Syuriyyah PCNU Jepara, KH Muhammad Amirul Wildan, Katib Syuriyah PCNU Jepara - Pengasuh Pondok Pesantren Mambaul Ulum Mayong Jepara, KH Zainal Umam Amin Pengasuh Pondok Pesantren Hasyim Asy'ari Bangsri - Wakil Bendahara PCLBM NU Jepara, Abdul Manan, Ketua PC Lembaga Takmir Masjid (LTM) NU Jepara, Dr. H. A. Barowi TM, M.Ag. (Ketua MWC NU Pakis Aji I Direktur Pascasarjana Unisnu Jepara), Muhammad Nashrullah Huda (Ketua PC Lembaga Bahtsul Masail NU Jepara).
Dalam kolom bahtsul masail pada website nujepara.or.id ini berisikan tentang berbagai masalah yang dijadikan tema tulisan, kemudian disertakan pembahasan dan hukum-hukumnya. Tulisan dalam kolom bahtsul masail ini dikirim dari LBMNU (Lembaga Bahtsul Masail Nahdlatul Ulama). Dari segi historis maupun operasionalitas, bahtsul masail merupakan forum yang sangat dinamis, demokratis dan berwawasan luas. Dikatakan dinamis sebab persoalan (masail) yang digarap selalu mengikuti perkembangan (trend) hukum di masyarakat.

Pemanfaatan website sebagai media dakwah dinilai sangat efektif dan efisien. Kerana website merupakan media komunikasi untuk menyampaikan informasi yang dibuat dengan biaya relatif murah, juga bisa menampilkan informasi dalam bentuk interaktif dibanding kertas konvensional pada umumnya. Selain itu, website nujepara ini bisa digunakan tidak terbatas pada komputer saja, tetapi bisa diakses via perangkat mobile, tablet dan gadget lainnya.

\section{Pemanfaatan Media Massa pada Organisasi Muhammadiyah}

Sama dengan pemaparan di atas bahwa peran media massa dalam sebuah organisasi sangat dekat hubungannya dengan peran public relations. Aktivitas Public Relations (PR) selalu dihubungkan dengan aktivitas komunikasi dalam organisasi $\mathrm{PR}$, sesuai dengan peran dan fungsinya, bertindak sebagai komunikator yang mewakili organisasi untuk menyampaikan atau menyebarluaskan pelbagai informasi kepada publik yang dijadikan sasaran, baik publik internal maupun publik ekstrenal 
(Ruliana, 2014:177). Oleh karena itu, dalam Ilmu Komunikasi PR merupakan suatu metode komunikasi dan telah menjadi begian dari objek studi ilmu komunikasi.

Media massa pada dasarnya dapat dibagi menjadi dua kategori, yakni media massa cetak dan media elektronik. Media cetak yang dapat memenuhi kriteria sebagai media massa adalah surat kabar dan majalah. Sedangkan media elektronik yang memenuhi kriteria media massa adalah radio, televisi, film, media on-line (internet).

Dalam organisasi keislaman Muhammadiyah Jepara, ada majelis yang menangani tentang media dan sarana informasi. Majelis yang lebih dikenal dengan sebutan MPI atau (Majelis Pustaka dan Informasi) ini mempunyai misi yaitu mewujudkan sistem informasi yang mencakup pengembangan pustaka dan informasi yang unggul, terintengrasi dan masif.

MPI memiliki peran yang sangat penting dalam mengembangkan sinergitas sumber daya teknologi informasi, pustaka dan media sebagai sistem gerakan maupun amal usaha di lingkungan Persyarikatan. Kemudian juga untuk menguatkan kapasistas kelembagaan internal Persyarikatan melalui pemanfaatan teknologi informasi dan media komunikasi yang maju, interkonektif dan modern.

Melalui MPI ini diharapkan dapat mengembangkan jaringan dengan berbagai pihak dalam bidang teknologi informasi, pustaka dan media dalam rangka perluasan dakwah Persyarikatan. Kemudian dapat mengoptimalkan sumberdaya kader bidang pustaka, teknologi informasi, dan media yang berkomitmen dan profesional dalam penguatan dan perluasan syiar Persyarikatan.

\section{a. Pemanfaatan Media Cetak}

Dalam berdakwah lewat media massa cetak, organisasi Muhammadiyah untuk saat ini belum mempunyai produk media cetak sendiri. Organisasi ini masih menggunakan sistem kerjasama dengan medialain, diantaranya bekerjasama dengan Pimpinan Pusat Muhammadiyah berupa Majalah Bulanan "Suara Muhammadiyah" dan Majelis Tabligh Yogyakarta berupa bulletin "Risalah Jum'at".

Suara Muhammadiyah merupakan majalah utama yang diterbitkan oleh Pimpinan Pusat Muhammadiyah sebagai media dakwah. Majalah suara Muhammadiyah mempunyai fungsi sebagai media komunikasi dan informasi warga persarikatan. Di samping itu, majalah suara Muhammadiyah juga merupakan bacaan yang dianjurkan atau wajib bagi pengurus dan pimpinan serta karyawan amal usaha Muhammadiyah.

Ada beberapa alasan mengapa Majalah Suara Muhammadiyah tidak hanya untuk kalangan anggota organisasi Muhammadiyah melainkan juga mencakup seluruh umat manusia. Di antara alasan tersebut adalah pertama, agar masyarakat tahu bahwa Muhammadiyah bukan hanya milik dan untuk warga Muhammadiyah saja melainkan juga untuk seluruh umat manusia. Kedua, sebagai bentuk komitmen dan kepedulian terhadap penyelenggara aktivitas dakwah yang dikembangkan oleh Muhammadiyah yang ditujukan kepada seluruh umat manusia. Ketiga, sebagai 
usaha untuk merealisasikan ajaran islam dalam kehidupan sehari-hari.

Sedangkan bulletin Risalah Jum'at merupakan bulletin yang diterbitkan oleh Majlis Tabligh Pimpinan Wilayah Muhamamdiyah Daerah Istimewa Yogyakarta. Bulletin risalah jum'at terbit setiap harijum' at. Buletin ini didistribusikan ke masjid-masjid yang ada di Kabupaten Jepara. Sasaran dari bulletin tersebut adalah warga Muhammadiyah dan masyarakat umum.

Bulletin "Risalah Juma'at" ini hanya memiliki satu halaman dan satu rubrik saja, memuat satu artikel atau esai yang berisi konten dakwah islamiyah dari berbagai penulis dan berbagai sumber. Isi artikel biasanya bersumber dari tulisan-tulisan tokoh agama Quraish Shihab, atau berisi tulisan dari berbagai tokoh Muhammadiyah lainnya.

Dipilihnya media ini karena buletin memiliki kelebihan, antara lain: pertama, buletin mudah untuk di miliki oleh masyarakat karena harganya relatif murah di banding dengan media cetak lainnya. Kedua, sesuai dengan karakteristiknya media ini dapat menyampaikan keanekaragaman informasi seperti artikel, konsultasi agama, serta ajaran-ajaran Islam lainya dapat dimaksukkan kedalamnya. Ketiga, buletin dapat di baca berulang kali sehingga dapat di pahami sampai mendetail.

Walaupun masih menggunakan sistem kerjasama dengan media lain, bulletin "Risalah Juma' $t$ " ini selalu rutin terbit dan rutin didistribusikan. Proses pendistribusian langsung dikirim dari
Yogyakarta ke kantor PDM Jepara. Untuk kemudian dibagikan kepada jamaa'ah sholat Jum'at di masjid Muhammadiyah Jepara.

Majelis Pustaka dan Informasi (MPI) Muhammadiyah dalam program kerjanya menyebutkan bahwa akan meneribitkan bulletin atau majalah secara independen, tetapi belum terlaksana. Harapan dari MPI Jepara hal itu bisa terwujud, karena memang media cetak dinilai sama-sama efektifnya sebagai media dakwah Muhammadiyah.

b. Pemanfaatan Media Elektronik

Media elektronik dibagi menjadi dua yaitu media audio berupa Radio dan media audio-visual berupa televisi. Organisasi Muhammadiyah Jepara dalam hal pemanfaatan media elektronik pernah menggunakan media Radio sebagai sarana media dakwah. Radio milik Pimpinan Daerah Muhammadiyah (PDM) Jepara ini .

\section{c. Pemanfaatan Media Online}

Aktivitas dakwah yang dilakukan banyak organisasi keislaman saat ini telah banyak menggunakan media penunjang yang efektif, efisien dan menarik bagi masyarakat luas. Salah satu media penunjang aktivitas publikasi dan dakwah adalah website yang merupakan bagian dari media internet/ media online. Website memiliki keunggulan dalam hal dakwah atau penyebaran informasi secara lebih efektif dibandingkan dengan media lain.

Pemanfaatan media online berupa website diterapkan organisasi Muhammadiyah Jepara sebagai media dakwah. Website resmi milik Muhammadiyah ini dikelola oleh MPI 
(Majelis Pustaka dan Informasi), dengan alamat url jepara.muhammadiyah.or.id.

Secaraumum, websiteMuhammadiyah ini terdiri dari Domain Utama (www yang dikelola PP) dan 548 Sub-Domain (8 subdomain Majelis tingkat PP, 7 sub-domain Lembaga tingkat PP, 10 subdomain terkait menu khusus, 33 sub-domain PWM dan 496 sub-domain PDM se-Indonesia). Jumlah sub-domain ini masih dapat berkembang sesuai kebutuhan.

Menu yang ada sekarang masih berjumlah sekitar 150 menu yang terdiri dari Menu Header, Menu samping dan Menu Footer. Tipe menu ada yang statis (seperti Profil, Sejarah, dll.) dan menu dinamis (berita, agenda, pengumuman, forum, bacaan se-hari-hari, download materials, dll.).

Menu dinamis memungkinkan dapat menampilkan konten-konten secara kompleks dan terorganisasi dengan baik, sehingga lebih mudah ditangkap dan diakses oleh pengguna. Misalnya menu berita, dalam hal ini dapat dikelompokkan berita PP, berita PWM, berita PDM, berita Majelis, berita Lembaga, dan bahkan berita organisasi otonom yang mempunyai situs berbeda, seperti Aisyiyah, Pemuda Muhammadiyah, NA, IMM dan lain-lain.

Website resmi Persyarikatan Muhammadiyah terdiri dari domain utama dan subdomain. Domain utama adalah www.muhammadiyah.or.id. Domain utama adalah halaman-halaman website milik Pimpinan Pusat Muhammadiyah yang akan dikelola bersama antara Majelis Pustaka dan Informasi beserta beberapa admin yang ditunjuk oleh PP Muhammadiyah.
Domain utama berisi kontenkonten utama tentang Persyarikatan Muhammadiyah secara keseluruhan, termasuk institusi-institusi pendukung, organisasi otonom serta PWM dan PDM seluruh Indonesia. Domain utama mengandung beberapa menu utama, termasuk berita, agenda, pengumuman, dan lain-lain.

Ibarat sebuah rumah, maka domain utama merupakan bangunan rumah secara keseluruhan dengan beberapa ruang/kamar sebagai sub-domain yang didistribusikan untuk majelis, lembaga, PWM, PDM dan lain-lain. Website organisasi otonom tidak berada di dalam bangunan utama, tetapi merupakan bangunan terpisah yang terhubung, karena semua organisasi otonom sudah mempunyai website sendirisendiri.

Admin dan pengelola domain utama bertanggungjawab memelihara domain dalam hal mengisi konten, menambah menu, merubah menu atau bahkan merubah desain. Termasuk mengelola iklan dalam berbagai ukuran dan tempat halaman yang berbeda-beda. Khusus berita, dalam hal ini perlu keaktifan admin untuk memasukkan berita Pimpinan Pusat Muhammadiyah sebagai berita utama dan memasukkan kembali berita-berita organisasi otonom. Semua berita yang dipublish oleh masingmasing sub-domain akan ditampilkan secara otomatis di domain utama. Demikian pula menu agenda dan pengumuman. Ter-update maupun tidaknya website ini hampir 75\% menjadi tanggungjawab admin domain utama. Mengingat pentingnya eksistensi website ini, maka tugas MPI dan 
admin-admin domain utama yang ditunjuk menjadi sangat sentral.

Seperti sudah dijelaskan di depan, sub-domain diibaratkan ruang/kamar yang ada di sebuah rumah. Website Muhammadiyah terdiri dari banyak subdomain. Setiap subdomain akan dikelola sendiri-sendiri oleh institusi yang diberi kewenangan sebagai admin sub-domain. Inilah maknanya website yang didesain secara dinamis. Pengelolaan menjadi lebih mudah karena dilakukan bersama-sama oleh banyak pihak secara terintegrasi. Subdomain yang sudah diberi nama untuk sementara berjumlah 548 sub-domain, misalnya: http://jepara.muhammadiyah. or.id; http://kudus.muhammadiyah. or.id; http:/ / demak.muhammadiyah.or.id; dan lain-lain. Semua majelis, lembaga, PWM, dan PDM sudah mempunyai subdomain sendiri-sendiri. Mereka diberi akses langsung ke website untuk bertindak sebagai admin sub-domain dengan login dan password berbeda.
Website Jepara.muhammadiyah.or.id ini menjadi sarana media dakwah satusatunya yang dikelola secara resmi oleh Majelis Pustaka dan Informasi.

\section{Gambar 3}

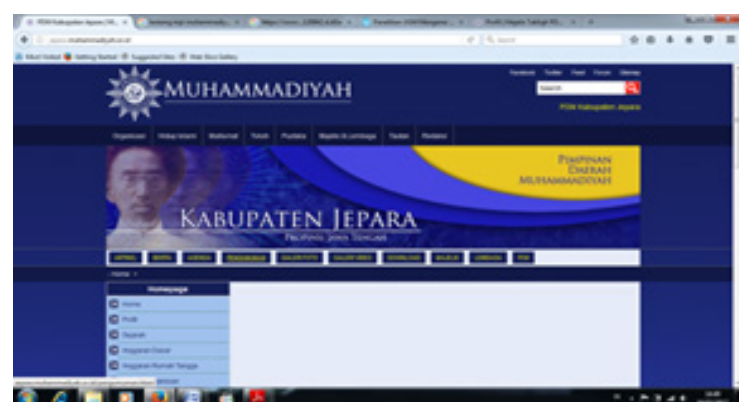

Sumber :

http://jepara.muhammadiyah.or.id/

Gambar 4

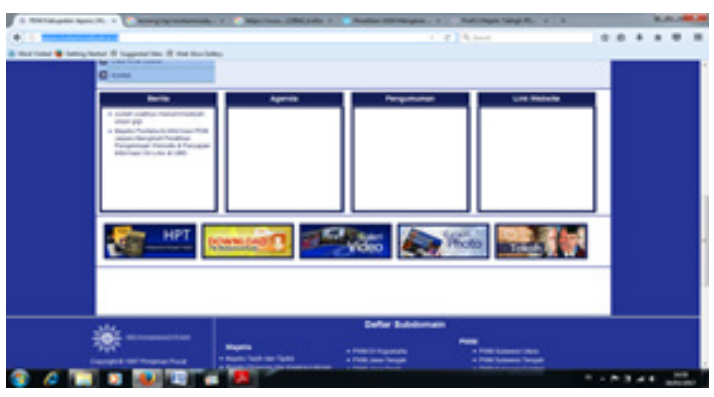

Sumber :

http://jepara.muhammadiyah.or.id/

Tabel 1. Perbandingan Pemanfaatan Media Massa

\begin{tabular}{|l|l|l|}
\hline Perbandingan & \multicolumn{1}{|c|}{ Nahdlatul Ulama } & \multicolumn{2}{|c|}{ Muhammadiyah } \\
\hline Media Massa Cetak & $\begin{array}{l}\text { Pemanfaatan media masaa cetak } \\
\text { pada organisasi Nahdlatul Ulama } \\
\text { masih menggunakan sistem } \\
\text { kerjasama dengan media lain. }\end{array}$ & $\begin{array}{l}\text { Pemanfaatan media massa } \\
\text { online pada organisasi } \\
\text { Muhammadiyah berjalan dengan baik. } \\
\text { belum }\end{array}$ \\
\hline $\begin{array}{l}\text { Media Massa } \\
\text { Elektronik }\end{array}$ & & \\
\hline $\begin{array}{l}\text { Media Massa } \\
\text { Online }\end{array}$ & & \\
\hline
\end{tabular}




\section{SIMPULAN}

Setelah penulis melakukan penelitian terhadap strategi pemanfaatan media massa pada organisasi Islam Nahdlatul Ulama dan Muhammadiyah Jepara, ada beberapa kesimpulan bahwa media massa yang digunakan dua organisasi ini adalah ; media massa cetak, media massa elektronik dan media massa online. Berikut kesimpulan dalam kajian ini:

\section{Pemanfaatan media oleh Nahdlatul Ulama dan Muhammadiyah Jepara}

a. Pemanfaatan media massa cetak berupa buku

Pemanfaatan media masaa cetak berupa buku pada organisasi Nahdlatul Ulama belum terealisasi, walaupun ada rencana dalam program kerja untuk menerbitkan karya tulisan berupa buku. Begitupula pemanfaatan media massa cetak berupa buku pada organisasi Muhammadiyah juga belum terealisasi, walaupun ada rencana dalam program kerja untuk menerbitkan karya tulisan berupa buku.

b. Pemanfaatan media massa cetak berupa surat kabar

Pemanfaatan media massa cetak berupa surat kabar pada organisasi Nahdlatul Ulama menggunakan sistem kerjasama dengan media massa cetak lain diantaranya ; Suara Merdeka, Jawa Pos. Menggunakan sistem press release dalam dakwah maupun publikasi kegiatan organisasi.

Begitupun dengan organisasi Muhammadiyah Jepara, sistem kerjasama dengan media massa cetak lain ; suara merdeka, jawa pos juga menggunakan press release.

c. Pemanfaatan media massa cetak berupa majalah/bulletin

Pada organisasi Nahdlatul Ulama, pemanfaatan media massa cetak elum mempunyai produk media massa cetak berupa majalah/ bulletin. Sedangkan pada organisasi Muhammadiyah pemanfaatan media massa cetak berupa majalah/ bulletin menggunakan kerjasama dengan media lain ; bekerjasama dengan Pimpinan Pusat Muhammadiyah berupa Majalah Bulanan "Suara Muhammadiyah" dan Majelis Tabligh Yogyakarta berupa bulletin “Risalah Jum'at.

d. Pemanfaatan media massa elektronik berupa radio

Organisai Nahdlatul Ulama menggunakan sistem kerjasama dengan radio R-lisa FM Jepara melalui Program acara reguler atau harian Tombo Ati (Kajian Al- Hikam Pagi), disiarkan sebagai acara khusus dakwah Islam. Acara tersebut dikemas berupa siaran ulang hasil rekaman pengajian bersama KH. Imron Djamil. Sedangkan organisasi Muhamamdiyah pernah memanfaatkan media elektronik berupa radio yang diberi nama Radio Kusuma FM pada tahun 2010.

e. Pemanfaatan media massa elektronik berupa Televisi

Organisasi Nahdlatul Ulama belum memanfaatkan media elektronik berupa televisi dalam hal berdakwah lewat media massa. Sama halnya Organisasi Muhammadiyah belum memanfaatkan media elektronik berupa televisi dalam hal berdakwah lewat media massa. 
f. Pemanfaatan media massa Online/ website

Pada organisasi Nahdlatul Ulama pemanfaatan media massa online sudah mempunyai website resmi dengan url www.nujepara.or id. Pemanfaatan yang menurut organisasi Nahdlatul Ulama paling efektif dan efisien dalam berdakwah dan publikasi organisasi. Sedangkan pada organisasi Muhammadiyah dalam pemanfaatan media online nya mempunyai website resmi dengan url www.jepara. muhammadiyah.or .id. Tetapi sejauh ini isi tulisan maupun berita dalam website masih terbatas.

\section{Perbandingan dan Persamaan Dua Organisasi}

Perbandingan dua organisasi ini dalam memanfaatkan media massa sebagai media dakwah terletak pada produk medianya. Organisasi Nahdlatul Ulama mempunyai beberapa produk media yang dijadikan sebagai sarana dakwah diantaranya ada website. Sedangkan Muhammadiyah pernah menggunakan radio sebagai media dakwah, walau sekarang sudah tidak beroperasi lagi.

Kesamaan dua organisasi ini yaitu sama-sama memanfaatkan media massa sebagai dakwah dengan sistem kerjasama dengan media lain. Nahdlatul Ulama kerjasama dengan media cetak surat kabar dan radio R-lisa FM Jepara. Sedangkan Muhammadiyah kerjasama dengan media cetak bulletin Majelis Tabligh Yogyakarta dan Majalah Suara Muhammadiyah dari Pusat.

\section{Kelebihan dan Kekurangan}

Kelebihan pemanfaatan media massa dalam organisasi Nahdlatul Ulama terletak pada pemanfaatan media massa online nya. Pemanfaatan media massa online memang menjadi altenatif dakwah di era teknologi saat ini. Dakwah lewat virtual dinilai sangat efektif dan efisien karena sistem yang cepat dan mudah, bukan hanya untuk yang menulis (dalam hal ini da'i) tetapi juga untuk pembaca website $\left(\right.$ mad' $^{\prime} u$ ).

Sama halnya dengan organisasi Muhammadiyah yang menggunakan media online website sebagai media dakwah. Muhammadiyah menilai pendakwah haruslah mengembangkann strategi komunikasi yang menarik minat objek dakwah. terutama objek dakwah yang melek informasi di era digital atau generasi internet.

Sedangkan kekurangan dari dua organisasi ini adalah pada ketidakmerataan memanfaatkan di semua media yang ada. Seperti halnya media massa cetak maupun elektronik. Keduanya sama-sama tidak memanfaatkan dua media massa tersebut. 


\section{DAFTAR PUSTAKA}

Abidin Djamalul, Komunikasi dan Bahasa Daerah, Jakarta: Gema Insani Press, 1996

Arikunto Suharsimi, Prosedur Penelitian, Jakarta: Rineka Cipta, 1992.

Cholis Abdullah, Dakwah Transformatif, Jakarta: PP LAKPESDAM, 2006.

Daymon Christine -Haoloway Immy, Metode-Metode Riset Kualitatif dalam Public Relation dan Marketing Communication, Bandung : Mizan Media Utama, 2008.

Hamidi, Teori Komunikasi dan Strategi Dakwah, Malang: UMM Press, 2010.

Hasil Musyawarah Kerja Cabang (MUSKERCAB) I Pengurus Cabang Nahdlatul Ulama tanggal 8 Mei 2016.

Hasil Musyawarah Kerja Cabang (MUSKERCAB) II Pengurus Cabang Nahdlatul Ulama tanggal 27 November 2016.

Hasil Tanfidz Musyda Muhammadiyah Kabupaten Jepara tahun 2016.

Hasyim Masykur, Merakit Negeri Berserakan, Surabaya: Yayasan 95, 2002.

Ilaihi Wahyu, Komunikasi Dakwah, Bandung: Remaja Rosda Karya, 2010.

John Vivian, Teori Komunikasi Massa, Jakarta : Kencana, 2008.

Khoiri Nur, Model dan Jenis Penelitian, Jepara: INISNU Jepara, 2006.

Mahmudin, Manajemen Dakwah Rasul, Jakarta: Restu Ilahi,2004.

Maryono, Manajemen Pendidikan Agama Islam UMY, Yogyakarta: Pasca Sarjana,UNY, 2003.
Riduwan, Belajar Mudah Penelitian untuk Guru, Karyawan dan Peneliti Pemula, Bandung: Alfabeta, 2005.

Siagian S.P., Manajemen Modern, Jakarta : Masa Agung, 1994.

Sugiyono, Metode Penelitian Bisnis, Bandung: CV. Alfabeta, 2004.

Suryabrata Sumadi, Metodologi Penelitian, Jakarta: PT Raja Garindo Persada, 1983.

Uchjana Effendy Onong, Dinamika Komunikasi, Bandung: Remaja Karya, 1986

Umar Husein, Metode Penelitian untuk Skripsi dan Tesis Bisnis, Jakarta: PT.Raja Grafindo Persada, 2009.

W. Litte John Stephen, Teori Komunikasi Theories of Human Communication, Jakarta: Salemba Humanika, 2009. 